\title{
RICE STEM BORER, Chilo agamemnon POPULATION FLUCTUATION AND RICE VARIETAL RESISTANCE EI-Hawary,I.S. ${ }^{(1)} ;$ M.A.EI-Naggar ${ }^{(2)}$ andElizabeath Z. henishen ${ }^{(2)}$ 1) Plant Protection Department, Faculty of Agriculture, Tanta University \\ 2) Field Crops Research Department, Plant Protection Research Institute, Agricultural Research Center
}

\begin{abstract}
Rice, Oryza sativa L. is a vital food crop for more half of the global population. Unfortunately, it is subjected to attacks of several insect pests, from which is the rice stem borer, Chilo agamemnon Bles, the key insect pest species in Egypt. Monitoring population fluctuation of the insect during 2013 and 2014 rice seasons revealed the peaks of immature stages, as well as dead heart and white symptoms. In both seasons, the larvae exhibited three peaks of abundance, with high population density during August and September. The same trend, two peaks of abundance, was recorded for dead hearts. High population densities of white heads were detected in August and September with distinct peaks by late August and late September. Evaluation of varietal resistance to the borer revealed that Egyptian Jasmine cultivar was susceptible to $C$. agamemnon, while three cultivars were moderately susceptible; Giza 178, Giza 181 and Giza 182. Both Sakha 101 and Sakha 104 proved to be resistant to the borer throughout the three seasons. Six cultivars exhibited moderate resistance; Giza 177, Giza 179, Sakha 102, Sakha 103, Sakha 105 and Sakha 106.
\end{abstract}

\section{INTRODUCTION}

Rice (Oryza sativa, L.) is one of the most important food crops allover the world, providing food for more half of the global population (FAO, 2004). It is a key source of employment and income for rural people who live in developing countries. Rice is grown on over 150 million hectares in more than 110 countries, and occupies one fifth of the world crop land under cereals (Leonard and Rwegasira, 2015).

The rice plants are subjected to attacks of more than 100 insect species, but only twenty of which can cause economic damage. In Egypt, the rice stem borer, Chilo agamemnon Bles. is the key insect pest. This insect infests rice stems during vegetative stage resulting in "dead heart" symptom, and resulting in "white head" symptom during reproductive stage. The latter symptom is directly and negatively affect the rice yield, as the plants can compensate for the damage during vegetative stage, but can not during reproductive stage.

From the main components of insect pest management are insect monitoring, and host-plant resistance. Monitoring insect pest population fluctuation is very important for decision makers to apply control measures at proper time (Hugar et al., 2014). Because the excessive applications of insecticides result in many problems in the environment, natural balance and 
human-being health, it has been necessary to enhance the role of host plant resistance (Pandy and Choubey, 2012).

The current study was conducted at the experimental farm of Sakha Agricultural Research Station during three successive rice seasons; 2013, 2014 and 2015. Population fluctuations of the rice stem borer, Chilo agamemnon Bles were monitored throughout the rice season, and susceptibility of twelve rice cultivars to the borer infestation was evaluated.

\section{MATERIALS AND METHODS}

\section{Population fluctuation of rice stem borer, Chilo agamemnon Bles in rice fields:}

The rice cultivar Giza 178 was sown in well-prepared nursery (as recommended) on the fifth of May in 2013 and 2014 seasons. One month after sowing, the rice seedlings were transported to the permanent field, and transplanted as 2-3 seedlings/hill at spacing of $20 \times 20 \mathrm{~cm}$ between rows and hills as recommended. Normal cultural practices were adopted, but without pesticides. Ten days after transplanting, samples of rice plants were cut at the soil surface, and examined for different stages of the C. agamemnon. Weekly samples were taken, as 1000 rice tillers (about 40-50 hills) per sample. The rice plants were dissected and insect immature stages were counted and recorded. In addition, numbers of tillers having dead heart or white head symptoms were counted and percentages of both symptoms were calculated.

\section{Varietal resistance to rice stem borer, Chilo agamemnon Bles.}

Twelve rice cultivars (Table 2), released and cultivated by rice growers, were obtained from seed companies, and sown in the nursery as recommended on the fifth of May in 2013 and 2014 rice seasons. One month after sowing, rice seedlings were transplanted as previously mentioned with studying the population fluctuation. For assessing dead heart, samples (1000 tillers) were taken randomly 30-40 days after rice transplanting (depending on cultivar duration) and plant, having dead heart or white head symptoms were counted. Thus, percentages of both symptoms were calculated according to the scale of RRTC (2012), the rice cultivars were categorized into resistant $(0-<3 \%$ white heads), moderately resistant $(3-<6)$, moderately susceptible (6$<9)$, susceptible $(9-<12)$ and highly susceptible $(>12 \%$ white heads).

\section{RESULTS AND DISCUSSION}

\section{Population fluctuation of rice stem borer, Chilo agamemnon Bles in rice fields:}

Data presented in Table (1) show the population fluctuations of larvae and pupae of the rice stem borer, C. agamemnon in rice fields of Giza 178. This cultivar was selected for the current study as it was categorized as a susceptible cultivar to the rice stem borer, according to RRTC (2012). In 2013 rice season (Table 1), the larval population density was low during June and gradually increased throughout July, to reach a peak of 13 borer 
larvae/1000 rice tillers on the $3^{\text {rd }}$ of August. Another larval peak was detected by late August and early September; $23-25$ larvae/1000 tillers. In general, the borer larvae were of high population density during September. However, these larvae are physiologically go into hibernation late in the season (Sherif, 1996).

The pupal population density was mostly low throughout the rice season, with only two small peaks of abundance; the first on $27^{\text {th }}$ of July ( 7 pupae/1000 tillers), and the second on 7 thh of September (10 pupae). As for dead hearts, the symptom of damage appearing during the vegetative stage, they were very low during June (0-3 dead hearts/1000 rice tillers), medium during July (6-10 dead hearts), and relatively high during August, which coincides with the maximum tillering stage of Giza 178 rice cultivar (Anonymous 2012). Results revealed the occurrence of two peaks of dead heart; 10 and 23 dead hearts $/ 1000$ tillers on $13^{\text {th }}$ of July, and on $17^{\text {th }}$ of August, respectively. The white head appeared by early August with 11 white heads $/ 1000$ rice tillers, and progressively increased in density to exhibit a big peak on $31^{\text {st }}$ of August (120 white heads/1000 tillers) and another peak of abundance (100 white heads/100 rice tillers) on $21^{\text {st }}$ of September.

Table (1): Population fluctuation of rice stem borer, C. agamemnon infestation in rice fields during 2013 rice season, Sakha Agricultural Research Station, Giza 178 cultivar

\begin{tabular}{|l|c|c|c|c|}
\hline \multirow{2}{*}{ Date of examination } & \multicolumn{4}{|c|}{ Per 1000 rice tillers } \\
\cline { 2 - 5 } & Larva & Pupa & Dead Heart & White Head \\
\hline June 15 & 0 & 0 & 0 & 0 \\
22 & 1 & 0 & 2 & 0 \\
29 & 3 & 1 & 3 & 0 \\
July 6 & 6 & 5 & 6 & 0 \\
13 & 2 & 0 & 10 & 0 \\
20 & 9 & 4 & 7 & 0 \\
27 & 10 & 7 & 8 & 0 \\
August 3 & 13 & 3 & 5 & 11 \\
10 & 4 & 2 & 5 & 17 \\
17 & 7 & 2 & 23 & 28 \\
24 & 9 & 3 & 11 & 71 \\
31 & 25 & 4 & 9 & 120 \\
September 7 & 23 & 10 & 0 & 85 \\
14 & 18 & 0 & 0 & 89 \\
21 & 20 & 0 & 0 & 100 \\
\hline Average/1000rice tillers & 10.00 & 2.73 & 5.93 & 34.73 \\
\hline
\end{tabular}

In 2014 rice season (Table 2), the larval population density was obviously higher than that of the former season. However, three peaks of larval occurrence were recorded; 17,35 and 62 larvae/1000 rice tillers on $29^{\text {th }}$ of July, 26thh of August and $23^{\text {rd }}$ of September. The pupae appeared in two peaks of occurrence; 7 and 9 pupae/1000 tillers on $22^{\text {nd }}$ of July and on $5^{\text {th }}$ of August. Also, the dead heart symptom exhibited two peaks of occurrence; 12 
and 25 individuals/1000 tillers on $15^{\text {th }}$ of July, and on $12^{\text {th }}$ of August. As for the infestation by white heads, the infestation was maximum (135 white heads $/ 1000$ rice tillers) on $2^{\text {nd }}$ of September and 96 white heads on $23^{\text {rd }}$ of September. Population fluctuation of different rice stem borer species were monitored by several investigators; e.g. Kabran and Chen (2007) and Sommro et al. (2013)

Table (2): Population fluctuation of rice stem borer, Chilo agamemnon infestation in rice fields during 2014 rice season, Sakha Agricultural Research Station, Giza 178 cultivar

\begin{tabular}{|l|c|c|c|c|}
\hline \multirow{2}{*}{ Date of examination } & \multicolumn{4}{|c|}{ Per 1000 rice tillers } \\
\cline { 2 - 5 } & Larva & Pupa & Dead Heart & White Head \\
\hline June 17 & 0 & 0 & 0 & 0 \\
24 & 0 & 0 & 5 & 0 \\
July 1 & 1 & 2 & 3 & 0 \\
8 & 8 & 4 & 4 & 0 \\
15 & 9 & 6 & 12 & 0 \\
22 & 11 & 7 & 7 & 0 \\
29 & 17 & 3 & 8 & 0 \\
August 5 & 11 & 9 & 5 & 0 \\
12 & 12 & 6 & 25 & 7 \\
19 & 23 & 5 & 20 & 31 \\
26 & 358 & 4 & 4 & 40 \\
September 2 & 22 & 3 & 0 & 135 \\
9 & 33 & 0 & 0 & 90 \\
16 & 41 & 0 & 0 & 87 \\
23 & 62 & 0 & 0 & 96 \\
\hline Average/1000rice tillers & 19.00 & 3.27 & 6.20 & 32.40 \\
\hline
\end{tabular}

Comparison between the results of both seasons, it is evident that most of infestation criteria were higher in the second season than in the first one.

\section{Varietal resistance to rice stem borer, C. Agamemnon:}

Based on dead hearts:

Data presented in Table (3) show the susceptibility of 12 rice cultivars to rice stem borer, C. agamemnon, expressed as dead hearts for three successive seasons; 2013, 2014 and 2015. The overall average revealed that ten cultivars had low dead heart percentages ranging between $0.17 \%$ (Sakha 104) and 2.78\% (Giza 181). The two cultivars; Giza 178 and Egyptian Jasmine suffered the highest levels of infestation; 4.23 and $5.55 \%$, respectively. Also, both Giza 178 and Egyptian jasmine proved to be the highest susceptible cultivars through the three years of study; $4.33,3.19$ and $5.16 \%$ for the former cultivar and $4.15,5.13$ and $7.18 \%$ for the latter one, respectively. 
Table (3): Susceptibility of rice cultivars to rice stem borer, $C$. agamemnon infestation, expressed as dead hearts Sakha Agricultural Research Station.

\begin{tabular}{|l|c|c|c|c|c|}
\hline \multirow{2}{*}{ Cultivar } & \multirow{2}{*}{ Type } & \multicolumn{4}{|c|}{ Dead heart \% } \\
\cline { 3 - 6 } & Ja13 & $\mathbf{2 0 1 4}$ & $\mathbf{2 0 1 5}$ & Average \\
\hline Giza 177 & Japonica & $1.21 \mathrm{~b}$ & $1.36 \mathrm{~b}$ & $2.15 \mathrm{~b}$ & 1.57 \\
Giza 178 & Indica x Japonica & $4.33 \mathrm{c}$ & $3.19 \mathrm{c}$ & $5.16 \mathrm{c}$ & 4.23 \\
Giza 179 & Indica x Japonica & $2.70 \mathrm{bc}$ & $3.11 \mathrm{c}$ & $1.18 \mathrm{a}$ & 2.33 \\
Sakha 101 & Japonica & $0.99 \mathrm{a}$ & $0.15 \mathrm{a}$ & $0.18 \mathrm{a}$ & 0.44 \\
Sakha 102 & Japonica & $1.33 \mathrm{~b}$ & $1.50 \mathrm{~b}$ & $2.09 \mathrm{~b}$ & 1.64 \\
Sakha 103 & Japonica & $1.44 \mathrm{~b}$ & $2.00 \mathrm{bc}$ & $0.96 \mathrm{a}$ & 1.47 \\
Sakha 104 & Japonica & $0.11 \mathrm{a}$ & $0.16 \mathrm{a}$ & $0.25 \mathrm{a}$ & 0.17 \\
Sakha 105 & Japonica & $1.19 \mathrm{~b}$ & $1.14 \mathrm{~b}$ & $0.66 \mathrm{a}$ & 1.00 \\
Sakha 106 & Japonica & $2.05 \mathrm{bc}$ & $1.60 \mathrm{~b}$ & $3.22 \mathrm{bc}$ & 2.29 \\
Giza 181 & Indica & $4.25 \mathrm{c}$ & $1.90 \mathrm{bc}$ & $2.18 \mathrm{~b}$ & 2.78 \\
Giza 182 & Indica & $1.25 \mathrm{~b}$ & $1.36 \mathrm{~b}$ & $2.17 \mathrm{~b}$ & 1.59 \\
Egyptian jasmine & Indica & $4.15 \mathrm{c}$ & $5.31 \mathrm{c}$ & $7.18 \mathrm{c}$ & 5.55 \\
\hline
\end{tabular}

\section{Based on white heads:}

Data presented in Table (4) show the susceptibility of 12 rice cultivars, expressed as white head during three successive rice seasons. Average of the three years show that the lowest susceptibile cultivar was Sakha 101 , with only $1.35 \%$ while head followed by Sakha 104 with $2.63 \%$. The highly infested cultivars were Giza 178, Giza 181 and Egyptian jasmine with $8.67,8.70$ and $10.73 \%$ white head\%, respectively. The remaining cultivars exhibited moderate susceptibility to the rice stem borer. From abovementioned data of dead hearts and white heads, it could be reported that rice cultivars expressed their reactions to rice stem borer infestation clearly in the reproductive stage, expressed as white heads. In addition, rice cultivars of japonica type were more resistant or tolerant to the borer infestation than were cultivars of indica type.

Table (4): Susceptibility of rice cultivars to rice stem borer, $C$. agamemnon infestation, expressed as white heads Sakha Agricultural Research Station.

\begin{tabular}{|l|c|c|c|c|c|c|}
\hline \multirow{2}{*}{ Cultivar } & \multirow{2}{*}{ Type } & \multicolumn{4}{|c|}{ White heads \% } & \multirow{2}{*}{ Category } \\
\cline { 2 - 6 } & & $\mathbf{2 0 1 3}$ & $\mathbf{2 0 1 4}$ & $\mathbf{2 0 1 5}$ & Average & \\
\hline Giza 177 & Japonica & $3.25 \mathrm{~b}$ & $4.29 \mathrm{~b}$ & $3.28 \mathrm{~b}$ & 3.61 & Moderately resistant \\
Giza 178 & Indica x Japonica & $7.01 \mathrm{c}$ & $9.30 \mathrm{~d}$ & $9.70 \mathrm{~d}$ & 8.67 & Moderately susceptible \\
Giza 179 & Indica x Japonica & $4.12 \mathrm{~b}$ & $5.12 \mathrm{c}$ & $4.66 \mathrm{~b}$ & 4.89 & Moderately resistant \\
Sakha 101 & Japonica & $1.56 \mathrm{a}$ & $1.20 \mathrm{a}$ & $1.28 \mathrm{a}$ & 1.35 & Resistant \\
Sakha 102 & Japonica & $4.11 \mathrm{~b}$ & $4.60 \mathrm{~b}$ & $5.12 \mathrm{bc}$ & 4.61 & Moderately resistant \\
Sakha 103 & Japonica & $4.05 \mathrm{~b}$ & $5.11 \mathrm{c}$ & $6.08 \mathrm{c}$ & 5.08 & Moderately resistant \\
Sakha 104 & Japonica & $3.02 \mathrm{ab}$ & $2.80 \mathrm{a}$ & $2.07 \mathrm{a}$ & 2.63 & Resistant \\
Sakha 105 & Japonica & $3.50 \mathrm{~b}$ & $3.77 \mathrm{~b}$ & $5.12 \mathrm{bc}$ & 4.13 & Moderately resistant \\
Sakha 106 & Japonica & $3.60 \mathrm{~b}$ & $4.89 \mathrm{bc}$ & $5.16 \mathrm{bc}$ & 4.55 & Moderately resistant \\
Giza 181 & Indica & $6.91 \mathrm{c}$ & $9.11 \mathrm{~d}$ & $10.07 \mathrm{de}$ & 8.70 & Moderately susceptible \\
Giza 182 & Indica & $6.90 \mathrm{c}$ & $8.12 \mathrm{~d}$ & $7.05 \mathrm{c}$ & 7.36 & Moderately susceptible \\
Egyptian jasmine & Indica & $7.20 \mathrm{c}$ & $12.60 \mathrm{e}$ & $12.39 \mathrm{de}$ & 10.73 & Susceptible \\
\hline
\end{tabular}


These results are in agreement with those of El-Habashy et al. (2015) who reported that Sakha 101 was the least infested cultivar, while Egyptian jasmine was the highest infested cultivar. According to RRTC report (2012), rice genotypes with white heads less than $7 \%$ are considered tolerant to the rice stem borer infestation.

\section{REFERENCES}

El-Habashy, M.M.; R.A.S. El-Shafey; G.B. Anis and S.A. Hammoud (2015). Yield potential of novel rice genotypes and effect of Trichogramma release and blast resistance in rice productivity. J. Plant Production, Mansoura University, 2(1): 1-18.

FAO (2004). Food and agriculture organization of the United Nations. The state of food security in the world, pp. 30-31.

Hugar, S.V.; M.I. Naik and M. Manjunath (2014). Effect of date of sowing on rice yellow stem borer, Scirpophaga incertulas Walker (Lepidoptera: Pyraustidae) in aerobic paddy. International J. Plant Protection, 7(1): 157-160.

Kabran, R. and Y. Chen (2007). Induces resistance in rice against insects. Bull. Entomol. Res., 97(4): 327-335.

Leonard, A. and G. Rwegasira (2015). Abundance and spatial dispersion of rice stem borer species in Kahama, Tanzania. Journal of Insect Science, 15(1): 120-125.

Pandy, S. and M.N. Choubey (2012). Management of yellow stem borer, Scirpophaga incertulas in rice. Agric. Sci. Digest, 32(1): 7-12.

RRTC (2012). Rice research and training center, Sakha Agricultural Research Station, Report of 2011 Rice Season Results.

Sherif, M.R. (1996). Yield losses in the Egyptian rice fields occurred by rice stem borer in relation to cultivar acerate and light trap catches. J. Agric. Sci., Mansoura Univ. 21(2): 4537-4545.

Soomro, N.M.; T.J. Orsani; M.H. Soomro; S. Malik and A.R. Dhuyo (2013). Effect of agronomic practices on yellow stem borer, Scirpophaga incertulas (Walker). Pak. J. Agric. Agril. Engg. 29(2): 146-154. 
تقلبـات تعداد ثاقبـة سـاق الأرز Chilo agamemnon Bles الصنفية للحشرة

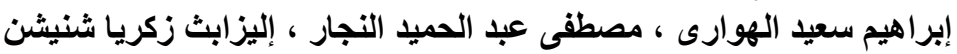

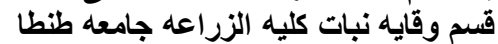
قسم افات محاصيل الحقل معهز وقايه النبات مركز البحوث الزراعيه

الأرز محصول غذائى حيوى لحو الى نصف سكان الكرة الأرضية. يهاجم المحصول الأقول

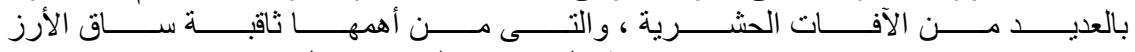
Chilo agamemnon Bles

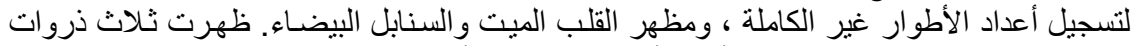

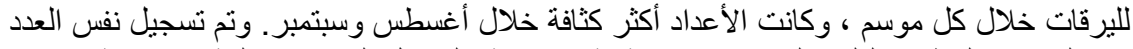



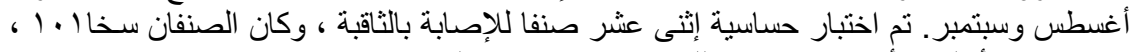

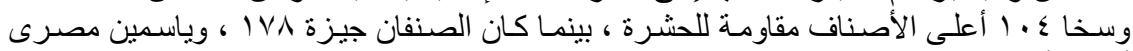
أكثر الأصناف إصابة بالثاقبة. 